\title{
Lasiodiplodia hormozganensis causing basal stem rot on Ricinus communis in Brazil
}

\author{
Fábio Alex Custódio ${ }^{1} \cdot$ Alexandre Reis Machado $^{2} \cdot$ Dartanhã José Soares $^{3} \cdot$ Olinto Liparini Pereira $^{1}$ (D)
}

Received: 7 May 2018 / Accepted: 13 July 2018 / Published online: 29 July 2018

(C) Australasian Plant Pathology Society Inc. 2018

\begin{abstract}
Ricinus communis plants showing symptoms of root and stem rot were observed in the states of Bahia and Paraíba, Brazil. Based on the morphology and phylogenetic analyses of ITS and TEF-1 $\alpha$ combined, the causal agents of the observed symptoms were identified as Lasiodiplodia hormozganensis and L. theobromae, pathogenicity was confirmed by fulfilling Koch's postulates. To our knowledge, this is the first report from any part of the world of L. hormozganensis causing root and stem rot in $R$. communis.
\end{abstract}

Keywords Botryosphaeriales $\cdot$ Biofuel $\cdot$ Phylogeny $\cdot$ Ricinus communis $\cdot$ Stem rot

Castor (Ricinus communis) is a non-edible oilseed crop belonging to the family Euphorbiaceae. This crop is of great importance to the chemical industry as a raw material used in a variety of products such as lubricants, pharmaceuticals, cosmetics, paints, and plastics, since it is the only commercial source of a hydroxylated fatty acid (Severino et al. 2012). In Brazil, castor is commonly cultivated in the semiarid areas of the Northeast region, where few diseases have been reported (Severino et al. 2012). During a survey of castor diseases in the states of Bahia and Paraiba, castor plants were found showing symptoms of stem, collar, and root rot, eventually resulting in plant demise. Symptoms were usually observed on adult plants during capsule maturing stages, despite soil type, but usually more frequent under waterdeficit stress. Symptomatic plants were collected in the field, and both roots and basal portion of the stem were

Olinto Liparini Pereira

oliparini@ufv.br

1 Departamento de Fitopatologia, Universidade Federal de Viçosa, Viçosa 36570-000, Brazil

2 Departamento de Micologia, Universidade Federal de Pernambuco, Recife 50740-600, Brazil

3 Empresa Brasileira de Pesquisa Agropecuária, Embrapa Algodão, Campina Grande 58428-095, Brazil relocated to the Plant Pathology Laboratory of Embrapa Algodão for examination. Black pycnidia with two-celled spores, initially hyaline but turning brown on maturity, were observed suggesting that a Lasiodiplodia sp. was associated with the symptoms. Up to now, only $L$. theobromae had been reported causing stem rot and also dieback of castor plants in Brazil. The dieback is usually a consequence of injury caused during the harvesting of racemes in biannual varieties (Batista et al. 1996; Lima et al. 1997). On the other hand, basal stem and root rot of castor plants in Brazil are usually associated with Macrophomina phaseolina (Severino et al. 2012; Claudino and Soares 2014). Thus, the aim of the present work was to elucidate the etiology of the Lasiodiplodia sp. associated with basal stem and root rot of castor plants in Brazil.

Isolation of Lasiodiplodia sp. was secured by direct transfer of the spore mass to Petri dishes filled with Potato Dextrose Agar (PDA), as well as by transferring small tissue fragments obtained from transition areas between healthy and symptomatic tissues. These fragments were disinfected in $70 \%$ ethanol for $1 \mathrm{~min}$ followed by $1 \%$ sodium hypochlorite for $3 \mathrm{~min}$ and washed in sterile distilled water. Approximately 50 samples showing stem and root rot symptoms were collected during abovementioned survey. From those, only six samples resulted in colonies with morphology compatible with Lasiodiplodia sp., while the majority were compatible 
with M. phaseolina. All six isolates obtained were deposited in the Coleção de Culturas de Microrganismos Fitopatogênicos of the Embrapa Algodão (CCMFCNPA) with accession numbers CCMF-CNPA 0553, CCMF-CNPA 554, CCMF-CNPA 0555, CCMF-CNPA 0556, CCMF-CNPA 585, and CCMF-CNPA 0603.

The isolates of Lasiodiplodia sp. obtained were grown in Petri dishes with 2\% Water Agar (WA - Agar Agar, type I Himedia $\left.{ }^{\circledR}\right)$ and incubated at $25{ }^{\circ} \mathrm{C}$ for 12 days. Subsequently, the growing tips of hyphae of colonies were cut out and transferred to Petri dishes with PDA. The isolates were grown on Petri dishes containing $2 \%$ WA overlaid with triple-sterilized corn straw and incubated at $25^{\circ} \mathrm{C}$ with a photoperiod of $12 \mathrm{~h}$ to induce the formation of pycnidia and spores. Observations, measurements and photographs were taken on an Olympus BX 53 microscope equipped with a digital camera Q-Color 5 Olympus.

All isolates had similar morphology: conidiomata stromatic, pycnidial, produced on corn straw on WA, superficial, dark, with an apical ostiole, stromatic wall composed of several layers of dark brown, thick-walled cells; conidia elipsoidal to cylindrical, one-celled and hyaline when immature, turning to dark brown, striate didymospores when mature (Fig. 1), typical of the genus Lasiodiplodia.

To extract genomic DNA, the isolates were grown on PDA at $25{ }^{\circ} \mathrm{C}$ for 1 week. Approximately $40 \mathrm{mg}$ of mycelia were collected and placed in a $2 \mathrm{~mL}$ microcentrifuge tube containing $600 \mu \mathrm{L}$ of Nuclei Lysis Solution of the Wizard ${ }^{\circledR}$ Genomic DNA Purification Kit (Promega Corporation, WI, U.S.A.), $100 \mathrm{mg}$ of Polyvinylpyrrolidone (PVP; Sigma-Aldrich Co.) and four steel beads. Next, the samples were mixed and crushed in the L-Beader 3 (Loccus Biotecnologia). After maceration, the extraction was continued as described by Pinho et al. (2012).

Target sequences of the Internal Transcribed Spacer regions 1 and 2 including the 5.8S rRNA gene (ITS) and Translation Elongation Factor 1- $\alpha$ (TEF1- $\alpha$ ) were amplified using primers ITS1 and ITS4 for ITS (White et al. 1990); EF1728F (Carbone and Kohn 1999) and EF2R (Jacobs et al. 2004) or EF1-688F (Alves et al. 2008) and EF1-986R (Carbone and Kohn 1999) for partial TEF1- $\alpha$. The PCR conditions and reagents were the same as those described by Machado et al. (2014).

Consensus sequences were compared against GenBank's database using their Mega BLAST program for a first identification. The ITS and TEF1- $\alpha$ sequences of additional species were retrieved from GenBank (Table 1) and aligned with sequences generated in this study using the multiple sequence alignment MUSCLE® program (Edgar 2004), an application of the MEGA v. 6 software program (Tamura et al. 2013). Alignments were checked, and manual adjustments were made where necessary.

Bayesian Inference (IB) analyses of the concatenated gene regions were performed as described by Machado
Fig. 1 Morphological characteristics of $L$. hormozganensis isolates, a colony of $L$. hormozganensis on PDA grown in the dark, $\mathbf{b}$ pycnidia with conidia exuded as a cirrus on corn straw, $\mathbf{c}$ Pycnidia releasing conidia immature hyaline, becoming pigmented with age, $\mathbf{d}$ conidia pigmented, septate and striate. Bars: $\mathrm{c}=$ $20 \mu \mathrm{m}, \mathrm{d}=20 \mu \mathrm{m}$

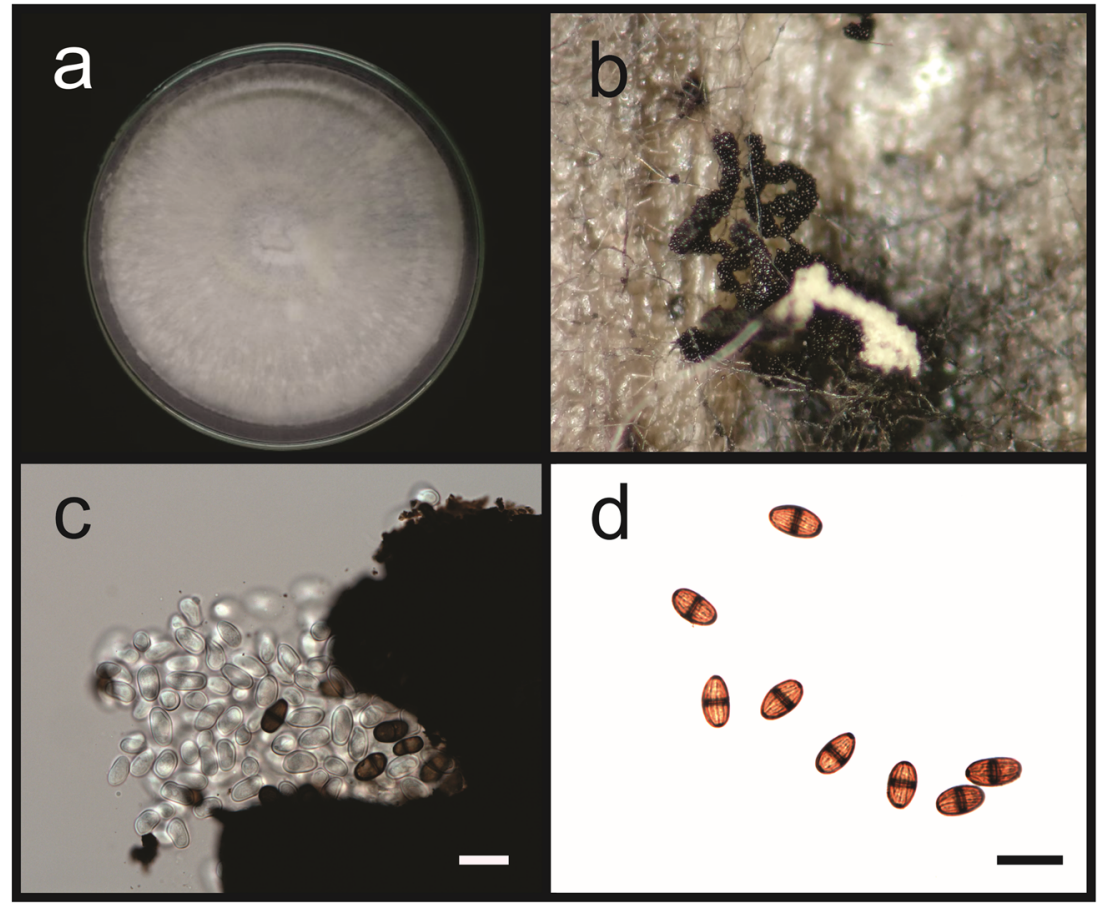


Table 1 Isolate number, location, host/substrate and genbank accession numbers of DNA sequences of Lasiodiplodia spp. used in phylogenetic analyses

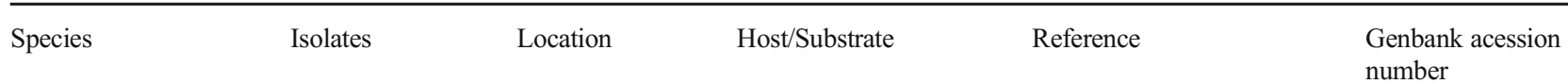

ITS TEF1- $\alpha$

\section{Lasiodiplodia brasiliense}

L. brasiliense

L. caatinguensis

L. caatinguensis

L. citricola

L. citricola

L. crassispora

L. crassispora

L. egyptiacae

L. egyptiacae

L. euphorbiicola

L. euphorbiicola

L. euphorbicola

L. exigua

L. exigua

L. gilanensis

L. gilanensis

L. gonubiensis

L. gravistriata

L. gravistriata

L. hormozganensis

L. hormozganensis

L. hormozganensis

L. hormozganensis

L. hormozganensis

L. hormozganensis

L. iraniensis

L. iraniensis

L. jatrophicola

L. jatrophicola

L. laeliocattleyae

L. laeliocattleyae

L. margaritacea

L. macrospora

L. mahajangana

L. mahajangana

L. mediterranea

L. mediterranea

L. missouriana

L. missouriana

L. parva

L. parva

L. plurivora

L. pontae

L. pseudotheobromae

L. pseudotheobromae

L. pyriformis

L. pyriformis

L. rubropurpurea

L. subglobosa

L. subglobosa

L. thailandica

L. thailandica

L. theobromae

L. theobromae

L. theobromae

L. theobromae

L. theobromae

L. venezuelensis

L. venezuelensis
CMM4015

CMM2313

IBL 40

CMM 1325

IRAN1521C

IRAN1522C

CBS110492

CMW22653

CBS130992

BOT-29

CMM3651

CMM3652

CMM3609

CBS 137785

BL 184

IRAN1523C

IRAN1501C

CBS115812

CMM 4564

CMM 4565

IRAN1500C

IRAN1498C

CCMF-CNPA 0553 Brazil

CCMF-CNPA 0555 Brazil

CCMF-CNPA 0603 Brazil

CCMF-CNPA 0556 Brazil

IRAN1517C Iran

IRAN1519C Iran

CMM3610 Brazil

CMM $4472 \quad$ Brazil

CBS $167.28 \quad$ Italy

LAREP1 Peru

CBS122519 Australia

CMM3833

CMW27801

CMW27820

CBS 137783

CBS 137784

UCD2193MO

UCD2199MO

CBS456.78

CBS495.78

STE-U5803

CMM1277

CBS116459

CMM3887

CBS 121770

CBS 121771

WAC 12536

CMM3872

CMM4046

CPC 22755

CPC22795

CBS164.96

CBS124.13

CBS111530

CCMF-CNPA 0554 Brazil

CCMF-CNPA 0585 Brazil

CMW13513 Venezuela

WAC12539 Venezuela
Madagascar

Madagascar

Italy

Italy

USA

USA

Colombia

Colombia

South Africa

Brazil

Costa Rica

Brazil

Namibia

Namibia

Australia

Brazil

Brazil

Thailand

Thailand

Papua New Guinea

USA

Unknown
Mangifera indica
Carica papaya
Spondias purpu

Spondias purpurea
Citrus sinensis

Citrus sp.

Citrus sp.

Unknown

Pterocarpus angolensis

Mangifera indica

Mangifera indica

Jatropha curcas

Jatropha curcas

Jatropha curcas

Retama raetam

Retama raetam

Unknown

Unknown

Syzygium cordatum

Anacardium humile

Anacardium humile

Olea sp.

Mangifera indica

Ricinus communis

Ricinus communis

Ricinus communis

Ricinus communis

Citrus sp.

Mangifera indica

Jatropha curcas

Anacardium occidentale

laeliocattleyae

Mangifera indica

Adansonia gibbosa

Jatropha curcas

Terminalia catappa

Terminalia catappa

Quercus ilex

Vitis vinifera

Vitis vinifera

Vitis vinifera

Cassava-field soil

Cassava-field soil

Vitis vinifera

Spondias purpurea

Gmelina arborea

Jatropha curcas

Acacia mellifera

Acacia mellifera

Eucalyptus grandis

Jatropha curcas

Jatropha curcas

Phyllanthus acidus

Mangifera indica

Fruit along coral reef coast

Unknown

Unknown

Ricinus communis

Ricinus communis

Acacia mangium

Acacia mangium
Netto et al. 2014

Netto et al. 2014

Coutinho et al. 2016

Coutinho et al. 2016

Abdollahzadeh et al. 2010

Abdollahzadeh et al. 2010

Burgess et al. 2006

Burgess et al. 2006

Ismail et al. 2012

Ismail et al. 2012

Machado et al. 2014

Machado et al. 2014

Machado et al. 2014

Linaldeddu et al. 2014

Linaldeddu et al. 2014

Abdollahzadeh et al. 2010

Abdollahzadeh et al. 2010

Pavlic et al. 2004

Netto et al. 2016

Netto et al. 2016

Abdollahzadeh et al. 2010

Abdollahzadeh et al. 2010

This study

This study

This study

This study

Abdollahzadeh et al. 2010

Abdollahzadeh et al. 2010

Machado et al. 2014

Netto et al. 2014

Rodríguez-Gálvez et al. 2016

Rodríguez-Gálvez et al. 2016

Pavlic et al. 2008

Machado et al. 2014

Begoude et al. 2010

Begoude et al. 2010

Linaldeddu et al. 2014

Linaldeddu et al. 2014

Úrbez-Torres et al. 2011

Úrbez-Torres et al. 2011

Alves et al. 2008

Alves et al. 2008

Damm et al. 2007

Coutinho et al. 2016

Alves et al. 2008

Machado et al. 2014

Slippers et al. 2014

Slippers et al. 2014

Burgess et al. 2006

Machado et al. 2014

Machado et al. 2014

Trakunyingcharoen et al. 2014

Trakunyingcharoen et al. 2014

Phillips et al. 2005

Alves et al. 2006

Alves et al. 2008

This study

This study

Burgess et al. 2006

Burgess et al. 2006

JX464063 JX464049

KC484793 KC481524

KT154762 KT154755

KT154760 KT008006

GU945353 GU945339

GU945354 GU945340

EF622086 EF622066

FJ888465 FJ888452

JN814397 JN814424

JN814401 JN814428

KF234553 KF226711

KF234554 KF226715

KF234543 KF226689

KJ638317 KJ638336

KJ638318 KJ638337

GU945351 GU945342

GU945352 GU945341

DQ458892 DQ458877

KT250949 KT250950

KT250947 KT266812 
Table 1 (continued)

\begin{tabular}{|c|c|c|c|c|c|c|}
\hline \multirow[t]{2}{*}{ Species } & \multirow[t]{2}{*}{ Isolates } & \multirow[t]{2}{*}{ Location } & \multirow[t]{2}{*}{ Host/Substrate } & \multirow[t]{2}{*}{ Reference } & \multicolumn{2}{|c|}{$\begin{array}{l}\text { Genbank acession } \\
\text { number }\end{array}$} \\
\hline & & & & & ITS & TEF1- $\alpha$ \\
\hline L. viticola & UCD2553AR & USA & Vitis vinifera & Úrbez-Torres et al. 2011 & HQ288227 & HQ288269 \\
\hline L. viticola & UCD2604MO & USA & Vitis vinifera & Úrbez-Torres et al. 2011 & HQ288228 & HQ288270 \\
\hline Diplodia mutila & CBS 136015 & Portugal & Populus alba & Alves et al. 2014 & KJ361838 & KJ361830 \\
\hline
\end{tabular}

ITS internal transcribed spacer regions 1 and 2, including the 5.8S ribosomal rRNA gene, TEF1- $\alpha$ translation elongation factor 1- $\alpha$

et al. (2014). The $\mathrm{K} 80+\mathrm{I}$ evolution models for the ITS region were used in the analyses while $\mathrm{HKY}+\mathrm{I}+\mathrm{G}$ was selected for TEF1- $\alpha$. The resulting trees were visualized in the Figtree v.1.3.1 program (Rambaut 2009) and later exported to graphic programs. Based on the results of combined phylogenetic analyses of ITS and TEF- $1 \alpha$ gene regions, four isolates were identified as Lasiodiplodia hormozganensis, since they grouped with the type isolate of L. hormozganensis (IRAN1500C), and two isolates were identified as $L$. theobromae, the tree was rooted to Diplodia mutila (CBS 136015) (Fig. 2).

For the pathogenicity test (Fig. 3), castor plants of BRS Energia cultivar, approximately 3 months old grown in a greenhouse, were inoculated with isolates obtained during the course of this study, using five plants per isolate. For inoculation, the isolates were grown in petri dishes with PDA at $25{ }^{\circ} \mathrm{C}$ for 7 days. Healthy plants had their stalks wounded with a sterilized scalpel and a 6-mm-diameter PDA disk containing mycelium of each isolate was deposited on the wound. A portion of cotton moistened with autoclaved distilled water was placed on each disk and then covered with plastic film for the first $48 \mathrm{~h}$ after inoculation to maintain moisture. The control treatment consisted of PDA plugs, with no fungus grown, deposited on the injured stalks as described above. The plants were then kept in a greenhouse for 30 days. All inoculated plants showed a necrosis and constriction on inoculation area and a severe wilt symptom. The fungus was re-isolated from the all inoculated plants and its identity was confirmed as previously described thereby satisfying Koch's Postulates. No fungus was re-isolated from control plants.

As above-mentioned, L. theobromae was already known to be associated to stem rot of castor plants in Brazil. On the other hand, L. hormozganensis was described in Iran associated with Olea sp. and Mangifera indica (Abdollahzadeh et al. 2010). In Brazil, this species has been reported to cause dieback in mango and grape, and stem-end rot in mango and papaya in the

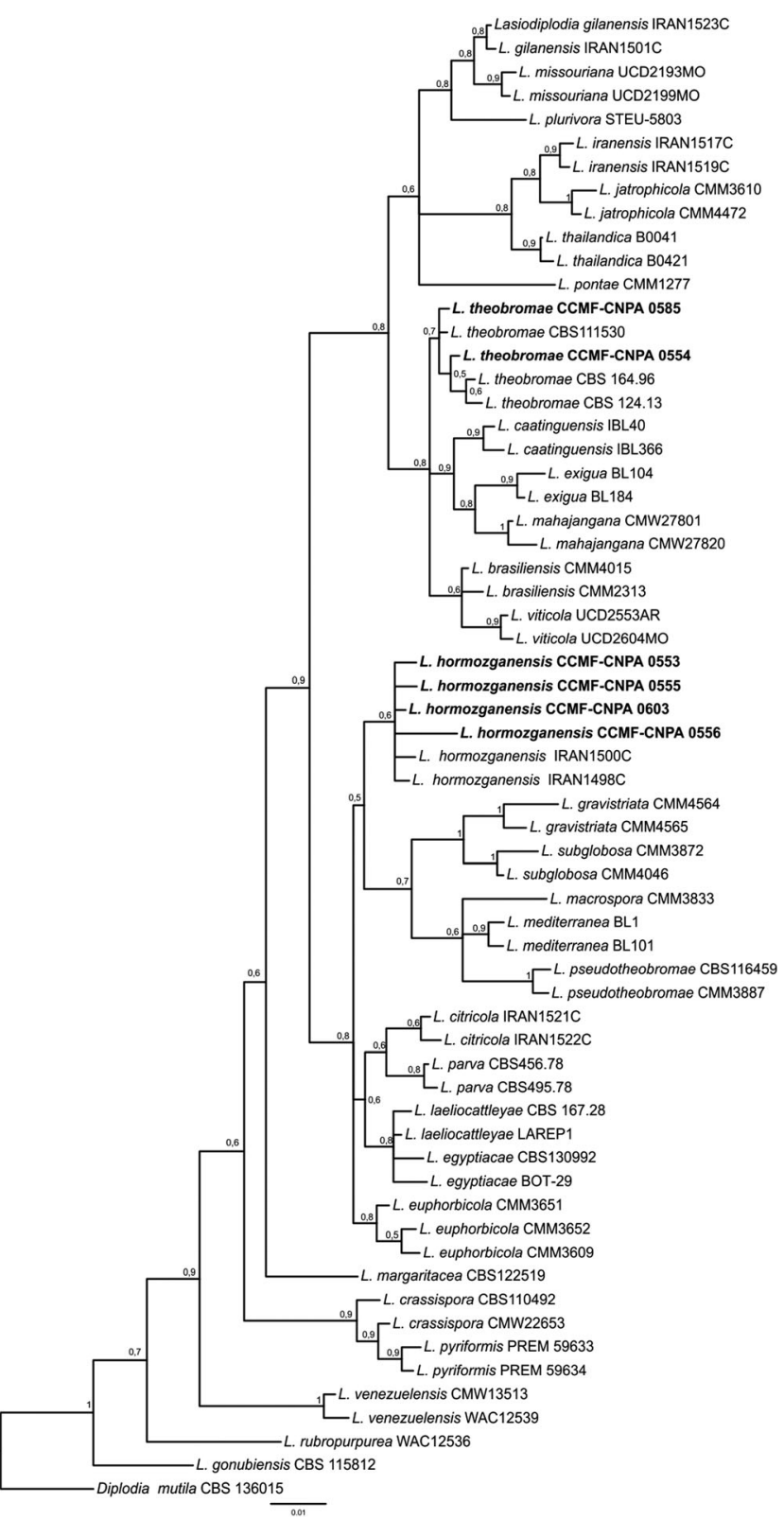

Fig. 2 Multilocus phylogenetic tree of Lasiodiplodia species inferred from Bayesian analysis based on the combined sequences of the ITS and TEF- $1 \alpha$. Bayesian posterior probabilities are indicated above the nodes and the tree was rooted to Diplodia mutila (CBS 136015). The bar represents the number of changes in the nucleotide sequence of each $100 \mathrm{bp}$. The species in this study are highlighted in bold 
Fig. 3 Pathogenicity test on $R$. communis, a control, b plant inoculated with Lasiodiplodia hormozganensis

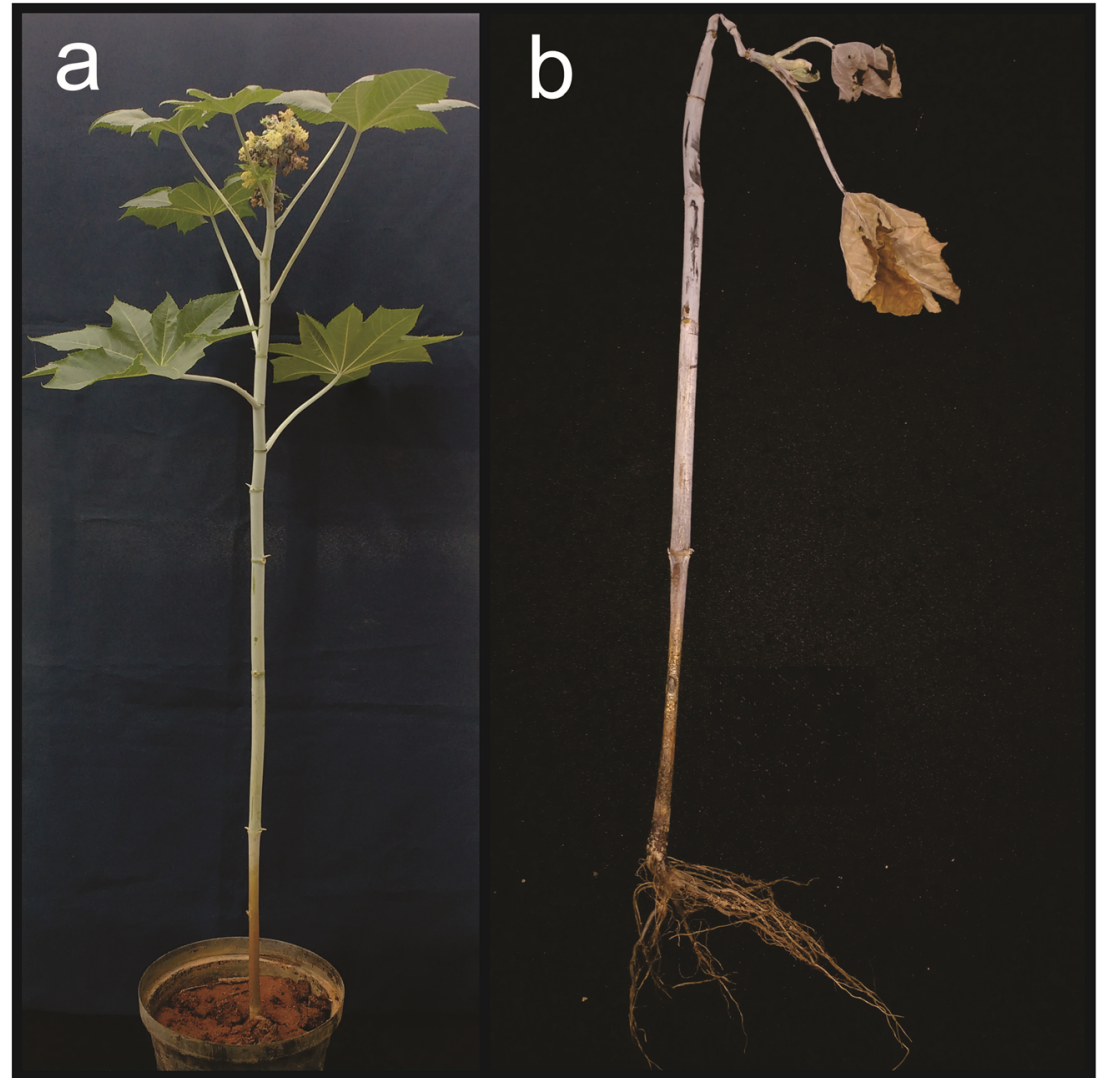

Northeast region of the country (Marques et al. 2013; Netto et al. 2014; Correia et al. 2015). Thus, the results of this work suggest this is the first report of $L$. hormozganensis causing basal stem and root rot on $R$. communis.

Acknowledgments The authors wish to thank Coordenação de Aperfeiçoamento de Pessoal de Nível Superior, Conselho Nacional de Desenvolvimento Científico e Tecnológico and Fundação de Amparo à Pesquisa do Estado de Minas Gerais for financial support.

\section{References}

Abdollahzadeh J, Jvadi A, Mohammadi-Goltapeh E, Zare R, Phillips AJL (2010) Phylogeny and morphology of four new species of Lasiodiplodia from Iran. Persoonia 25:1-10

Alves A, Correia A, Phillips AJL (2006) Multi-gene genealogies and morphological data support Diplodia cupressi sp. nov., previously recognized as $D$. pinea f. sp. cupressi, as a distinct species. Fungal Divers 23:1-15

Alves A, Crous PW, Correia A, Phillips AJL (2008) Morphological and molecular data reveal cryptic species in Lasiodiplodia theobromae. Fungal Divers 28:1-13

Alves A, Linaldeddu B, Deidda A, Scanu B, Phillips AJL (2014) The complex of Diplodia species associated with Fraxinus and some other woody hosts in Italy and Portugal. Fungal Divers 67:143-156
Batista FAS, Lima EF, Soares JJ, Azevedo DMP (1996) Doenças e pragas da mamoneira (Ricinus communis L.) e seu controle. EMBRAPACNPA Circular Técnica 21:6-19

Begoude BAD, Slippers B, Wingfield MJ, Roux J (2010) Botryosphaeriaceae associated with Terminalia catappa in Cameroon, South Africa and Madagascar. Mycol Prog 9:101-123

Burgess TI, Barber PA, Mohali S, Pegg G, de Beer W, Wingfield MJ (2006) Three new Lasiodiplodia spp. from the tropics, recognized based on DNA sequence comparisons and morphology. Mycologia 98(3):423-435

Carbone I, Kohn LM (1999) A method for designing primer sets for speciation studies in filamentous ascomycetes. Mycologia 91(3): $553-556$

Claudino MR, Soares DJ (2014) Pathogenicity and aggressiveness of Macrophomina phaseolina isolates to castor (Ricinus communis). Trop Plant Pathol 39(6):453-445

Correia KC, Silva MA, de Morais MA Jr, Armengol J, Phillips AJL, Camara MPS, Michereff SJ (2015) Phylogeny, distribution and pathogenicity of Lasiodiplodia species associated with dieback of table grape in the main Brazilian exporting region. Plant Pathol 65(1):92-103

Coutinho IBL, Freire FCO, Lima CS, Lima JS, Gonçalves FJT, Machado AR, Silva MAS, Cardoso JE (2016) Diversity of genus Lasiodiplodia associated with perennial tropical fruit plants in northeastern Brazil. Plant Pathol 66(1):90-104

Damm U, Crous PW, Fourie PH (2007) Botryosphaeriaceae as potential pathogens of Prunus species in South Africa, with descriptions of Diplodia africana and Lasiodiplodia plurivora sp. nov. Mycologia 99(5):664-680

Edgar RC (2004) MUSCLE: multiple sequence alignment with high accuracy and high throughput. Nucleic Acids Res 32:1792-1797 
Ismail AM, Cirvilleri G, Polizzi G, Crous PW, Groenewald JZ, Lombard L (2012) Lasiodiplodia species associated with dieback disease of mango (Mangifera indica) in Egypt. Australas Plant Pathol 41(6): 649-660

Jacobs K, Bergdahl DR, Wingfield MJ, Halik S, Seifert KA, Bright DE, Wingfield BD (2004) Leptographium wingfieldii introduced into North America and found associated with exotic Tomicus piniperda and native bark beetles. Mycol Res 108:411-418

Lima EF, Batista FAS, Azevedo DMP (1997) Podridão-do-caule e podridão-dos-ramos da mamoneira causada por Botryodiplodia theobromae pat. Pesq Agrop Brasileira 32(2):229-233

Linaldeddu BT, Deidda A, Scanu B, Franceschini A, Serra S, BerrafTebbal A, Zouaoui Boutiti M, Ben Jamaa ML, Phillips AJL (2014) Diversity of Botryosphaeriaceae species associated with grapevine and other woody hosts in Italy, Algeria and Tunisia, with descriptions of Lasiodiplodia exigua and Lasiodiplodia mediterranea sp. nov. Fungal Divers 71:201-214

Machado AR, Pinho DB, Pereira OL (2014) Phylogeny, identification and pathogenicity of the Botryosphaeriaceae associated with collar and root rot of the biofuel plant Jatropha curcas in Brazil, with a description of new species of Lasiodiplodia. Fungal Divers 67(1): 231-247

Marques MW, Lima NB, Morais JRMA, Barbosa MAG, Souza BO, Michereff SJ, Phillips AJL, Camara MPS (2013) Species of Lasiodiplodia associated with mango in Brazil. Fungal Divers 61: 181-193

Netto MSB, Assunção IP, Lima GSA, Marques MW, Lima WG, Monteiro JHA, Balbino VQ, Michereff SJ, Phillips AJL, Câmara MPS (2014) Species of Lasiodiplodia associated with papaya stemend rot in Brazil. Fungal Divers 67(1):127-141

Netto MSB, Lima WG, Correia KC, da Silva CFB, Thon M, Martins RB, Miller RNG, Michereff SJ, Câmara MPS (2016) Analysis of phylogeny, distribution and pathogenicity of Botryosphaeriaceae species associated with gummosis of Anacardium in Brazil, with a new species of Lasiodiplodia. Fungal Biol 121(4):437-451

Pavlic D, Slippers B, Coutinho TA, Gryzenhout M, Wingfield MJ (2004) Lasiodiplodia gonubiensis sp. nov., a new Botryosphaeria anamorph from native Syzygium cordatum in South Africa. Stud Mycol 50(2):313-322

Pavlic D, Wingfield MJ, Barber PA, Slippers B, Hardy GESJ, Burgess TI (2008) Seven new species of the Botryosphaeriaceae from baobab and other native trees in Western Australia. Mycologia 100(6):851866

Phillips A, Alves AJL, Correia A, Luque J (2005) Two new species of Botryosphaeria with brown, 1-septate ascospores and Dothiorella anamorphs. Mycologia 97(2):513-529

Pinho DB, Firmino AL, Ferreira Junior WG, Pereira OL (2012) An efficient protocol for DNA extraction from Meliolales and the description of Meliola centellae sp. nov. Mycotaxon 122:333-345

Rambaut A (2009) FigTree 1.2.2. http://tree.bio.ed.ac.uk/software/ figtree/. Accessed 15 Jan 2017

Rodríguez-Gálvez E, Guerrero P, Barradas C, Crous PW, Alves AJL (2016) Phylogeny and pathogenicity of Lasiodiplodia species associated with dieback of mango in Peru. Fungal Biol 121(4):452-465

Severino LS, Auld DL, Baldanzi M et al (2012) A review on the challenges for increased production of castor. Agron J 104(4):853-880

Slippers B, Roux J, Wingfield MJ, van der Walt FJJ, Jami F, Mehl JWM, Marais GJ (2014) Confronting the constraints of morphological taxonomy in the Botryosphaeriales. Persoonia 33:155-168

Tamura K, Stecher G, Peterson D, Filipski A, Kumar S (2013) MEGA6: molecular evolutionary genetics analysis version 6.0. Mol Biol Evol 30:2725-2729

Trakunyingcharoen T, Lombard L, Groenewald JZ, Cheewangkoon R, To-anun C, Crous PW (2014) Caulicolous Botryosphaeriales from Thailand. Persoonia 34:87-99

Úrbez-Torres JR, Peduto F, Striegler RK, Urrea-Romero KE, Rupe JC, Cartwright RD, Gubler WD (2011) Characterization of fungal pathogens associated with grapevine trunk diseases in Arkansas and Missouri. Fungal Divers 52:169-189

White TJ, Bruns T, Lee S, Taylor JW (1990) Amplification and direct sequencing of fungal ribosomal RNA genes for phylogenetics. In: Innis MA, Gelfand DH, Sninsky JJ, White TJ (eds) PCR protocols: a guide to methods and applications. Academic Press INc., New York, pp 315-322 